\title{
Research on International Protection of Trademarks under the Background of "The Belt and Road"
}

\section{Fang Wang}

Law School of China University of Political Science and Law, Beijing, 100088

\author{
Keywords: International Protection, Trademarks, "The Belt and Road”
}

\begin{abstract}
The Belt and Road" (English: The Belt and Road, abbreviation B\&R) is the abbreviation of "Silk Road Economic Belt" and "21st Century Maritime Silk Road". The "Belt and Road" is a historical tradition that continues the "Silk Road". It is intended to strengthen the economic, cultural and political ties of the countries along the "Belt and Road" and seek common ground while reserving differences in order to achieve the goal of seeking common development of all countries in the world. In 2013, as an advocate of the "Belt and Road" concept, China has successively proposed major strategic proposals for the "Silk Road Economic Belt" and the "21st Century Maritime Silk Road", which have received high attention and support from the international community. With the promotion of the "Belt and Road" construction, the economic trade between China and the rest of the world has taken on a new look. The import and export transaction volume of goods and services has reached a new height, which has promoted the transnational flow of trademarks. As a mark of distinguishing goods and service sources, trademarks contain economic value that cannot be ignored. Trademark rights, as the basis of rights of trademark owners to protect their legitimate rights and interests, should be strengthened. Infringement of trademark infringement will inevitably occur. In the context of the "Belt and Road", the international protection of trademarks has become an issue of concern to all countries due to differences in the legal provisions of trademark laws.
\end{abstract}

\section{History of Trademark International Protection}

In the mid-to-late 19th century, the commodity economy of all countries in the world was growing, and the international competition for goods and services became more and more obvious. The import and export of goods and services in world trade played a corresponding role in the transnational flow of trademarks. In order to seize the international market, large-scale enterprises in various countries have registered trademarks in the importing countries of goods or services, which has triggered the urgent need for international protection of trademarks and promoted the internationalization of trademark protection. The most typical of the international conventions on trademarks is the 1883 Paris Convention, the earliest convention for the protection of industrial property rights. Many of the principles, such as the principle of national treatment, the principle of regionality, the principle of independence, and the principle of priority, are the world's Most countries adhere to it and refer to it as a national legislation. China is also a member of the Convention. The world is developing with each passing day. International conventions should also be updated with the changes and development of the world to adapt to the needs of international trademark protection. In 1891, Madrid signed the Madrid Agreement, which is an international treaty for international trademark registration. Signed by the country, the applicant for the international trademark registration must be a national of the member states of the Madrid Agreement and a non-member national who has a place of residence or business place in the member state. After the applicant obtains the international trademark registration, the trademark is in the Madrid Agreement. Member states can be automatically protected. However, the applicant's trademark still needs to be registered with the WIPO International Bureau after it has been registered in the country. Due to the many shortcomings of the Madrid Agreement, the WIPO organization signed the Madrid Protocol in 1989, and most of the members of the Madrid Agreement ratified it. The Madrid Agreement is closely linked to the Madrid Protocol, which is 
known as the "new developed version" of the Madrid Agreement. However, the Madrid Agreement and the Madrid Protocol are two separate legal documents. The members of the Protocol and Agreement are mainly developing countries, and China has acceded to the Agreements and Protocols. However, it seems that there is no attraction for developed countries. Developed countries with the United States, Japan, and the United Kingdom have not yet joined the agreement and protocol.

\section{The Challenge of Trademark International Protection}

\subsection{Regionality of Trademark Rights}

The fundamental reason for the challenging international protection of trademark rights is the territoriality of trademark rights. The territoriality of trademark rights is derived from the "territorial principle" in international law. It means that the trademark rights enjoyed by trademark registrants can only be granted in this right. It is protected in the national sphere and does not have legal effect in other countries. Trademark rights are considered to be domestic in nature in traditional thinking, and the trademark rights of one country are independent of the trademark rights of another. In the absence of a multilateral treaty to create a single right between member states (such as the EU trademark), or in accordance with the "famous trademark" in the Paris Convention, ownership of a trademark in one country does not mean that it is the same in another. Have this right unless all the conditions under which the relevant country is obtained are met.

\subsection{Differences in Religion and Culture}

The history of the countries along the "Belt and Road" stretches for a long time. In the long history of development, countries have formed distinctive cultural and religious beliefs. Therefore, when registering trademarks in various countries, we must pay attention to the religious beliefs and customs of each country. Customary legal environment differences

The cultures, values, customs and habits of trademarks in different countries are not the same. The laws and principles followed in the formulation of trademark laws are different. Therefore, the scope of protection and the focus of trademark laws and regulations vary from country to country. For example, the acquisition of trademark exclusive rights, some countries adopt useism, some countries adopt registrarism, some countries conduct substantive examinations, some countries conduct formal examinations, and some countries do not even conduct examinations. The same legal language may also be interpreted as different meanings in the laws of different countries. For example, in the Paris Convention, a member state may refuse to register or protect a trademark that is "sufficient to deceive the public".

\section{3. "The Belt and Road" Concept Gives Opportunities for International Protection of Trademarks}

"One Belt and One Road" can break the regional restrictions on trademark protection, promote the internationalization of trademark laws, accelerate the internationalization of trademark protection, and the internationalization of trademark protection brings great opportunities for the international protection of trademarks. Most of the countries along the "Belt and Road" have joined the international conventions with world influence such as the Paris Convention and the Madrid Agreement. These international conventions have made the content of international trademark standards more perfect, and the protection standards of international trademark rights have reached a higher level. The countries along the "Belt and Road" countries that join these international conventions must abide by relevant principles, guidelines and systems, and countries have reached a consensus on trademark protection to the utmost extent.

The countries along the "Belt and Road" include the 10 member countries of ASEAN, the 18 countries of West Asia, the eight countries of South Asia, the five countries of Central Asia, the seven countries of the Commonwealth of Independent States, and the sixteen countries of Central and Eastern Europe. The coalition countries with common economic interests are strengthening 
economic cooperation among countries. On the basis of this, we are also improving the intellectual property legal protection system and working together to strengthen intellectual property cooperation. Countries have great enthusiasm for cooperation and can fully refer to this model in conjunction with relevant conditions in this economic region. For example, in the ten ASEAN countries, in 1995, member states strengthened their mutual understanding and promoted the economic development of ASEAN in order to achieve close cooperation in intellectual property rights and related fields. They signed the ASEAN IP Framework Agreement (below). One of the cooperation objectives stipulated in the framework agreement is to explore the ASEAN unified trademark system.

Countries along the "Belt and Road" can speed up the internationalization of the trademark legal system, develop trademark legislation in an international direction, establish an international system for trademark registration, reach a unified trademark registration standard, and promote national trademark legislation along the "Belt and Road".

\section{The Internationalization of Trademark Law Challenges China}

As a major trademark country, China has also joined many international conventions on trademarks and international treaties. These joining actions have played an invaluable role in the protection of trademarks in China. The internationalization of trademark law has accelerated the process of China's trademark legislation, improved the content of China's trademark protection, and improved the protection level of China's trademarks. But at the same time, the internationalization of trademark laws has also brought serious challenges to the protection of trademarks in China.

Based on the limitations of China's economic level and legislative level, the gaps in China's current trademark legislation cannot be highly compatible with world trademark legislation and cannot fully meet the requirements of the international. Regarding the trademark use system, the provisions of the Trademark Law of China are not perfect. Although there are special laws and regulations on the use of trademarks in China's Trademark Law, there are reasonable concerns about the concerns and regulations in national legislations with representative significance. There is no provision, and at the same time, only the legislation surrounding the distinctive features of trademarks, mainly for the purpose of judging judgments, does not exhaustively list the conditions and methods of fair use.

Among the large number of legislative gaps in China's trademark law, the issue of parallel imports is an urgent problem to be solved. Parallel import, also known as genuine output, means that in the international trade, when an intellectual property right (patent, trademark or copyright) is protected by two or more countries, it is not authorized by the intellectual property owner or the exclusive licensee. The third party carried out the act of importing $C$ to sell the intellectual property product. Extending to the trademark issue, in international trade, a country's importer imports and sells the products or services identified by the trademark without the consent of the domestic trademark owner or the trademark exclusive licensee. However, China's Trademark Law does not stipulate parallel import issues. It is right or wrong and cannot be relied upon.

The "Belt and Road" has brought many opportunities and developments to China's trademark protection, but it has also brought many problems. While grasping the opportunity for development, China must also deal with problems. The solution to the problem is to further improve the trademark legal system, combine the national conditions, adopt the principle of strengths and weaknesses for the international trademark system, take its essence, remove its dross, take the national interest as the starting point, and protect the trademark of the country as the foothold. There are:

Under certain conditions, the legislature and administrative organs shall take the initiative to determine whether a trademark is well-known. For example, the Haier trademark should not be used in accordance with the law for the recognition of well-known trademarks at home and abroad. In addition, the author has several suggestions for determining whether a trademark is well-known: Whether it is a registered trademark should not be a hindrance to the recognition of a well-known trademark. Second, whether it is significant should not become the standard of recognition of 
well-known trademarks.

Through legislation, the system for the rational use of trademarks is clarified. Reasonable use of the mark includes descriptive use, indicative use, reasonable control or reproduction and non-commercial use. China's "Trademark Law" should clearly stipulate in the form of a law: permit the reasonable use of the above-mentioned forms of trademarks under certain conditions, and is not considered to be an infringement.

The TRIPS Agreement circumvents the issue of parallel imports because of the mixed attitudes of countries towards parallel imports. Parallel imports are closely related to trademark rights. Based on China's current economic level and internationalization level, it is still impossible to achieve a high degree of agreement. It also needs a large amount of foreign investment to learn the world's current technology. Parallel imports will infringe on the economic interests of trademark owners or exclusive licensees, and will also impact the domestic market. The investment environment undermines the balance of import and export trade. According to the practices of the EU, the United States and other countries or in combination with their legal principles, China's regulations on allowing parallel imports under certain conditions are formulated. For example, the source of parallel imports is marked with a distinctive identifier.

\section{Conclusion}

China has put forward the "One Belt, One Road" concept, and advocates the active participation of countries along the line and even the world, and strives for cooperation and mutual benefit, and advocates along the line of countries to work together and toward each other. The "One Belt, One Road" concept promotes the international protection of trademarks, breaks the regional restrictions on the protection of trademark rights, accelerates the process of internationalization of trademark laws, and brings opportunities for the protection of trademarks. However, the internationalization of trademark laws is a double-edged sword. There are also disadvantages. The vision of a country with a trademark law is not necessarily the common interest of all countries. Therefore, in the context of China's “One Belt, One Road” initiative, it has initiated an international cooperation on trademarks, led the organization of an international conference on intellectual property rights, and signed legal documents including international protection of trademarks. In the context of the "Belt and Road", China as the proponent of the concept should fully fulfill the role of the initiator and encourage the countries along the line to carry out trademark cooperation, including but not limited to signing regional trademark treaties and setting up international trademark institutions.

The internationalization of trademark law has obvious challenges to China's trademark law. We should take the initiative to attack on the national conditions, face the shortcomings and defects in the trademark law, improve the legislation, improve the legal system of trademark protection, and continuously improve the level of trademark legislation.

\section{References}

[1] Zhang Huibin. On the Constitutional Basis of Trademark Right_-Taking the Changes of American Law as a Clue[J]. Journal of Xidian University(Social Science Edition), 2017, 27(3): 82-88.

[2] Wu Chunyan, Zheng Youde. On the Coordination between China's Trademark Law and International Trademark System[J]. Science Technology and Law, 2001(3): 90-96.

[3] Zou Jialing, Liu Chunla, Yin Guoqing, et al. Trade pattern and economic contribution of China along the "Belt and Road" countries[J]. Advances in Geography, 2015, 34(5): 598-605.

[4] Xue Yuan. The Impact of the Entry into Force of the Singapore Treaty on the Development of International Trademark Legislation [J]. Intellectual Property, 2009, 19(3): 84-89.

[5] Xue Yuan. International Trademark Legislation in the Post-TRIPs Era: From Minimum Protection to Unification of Rules [J]. Politics and Law Forum: Journal of China University of 
Political Science and Law, 2011, 29(4): 97-106.

[6] Ren Yi. The Differences and Perfection of China's Trademark Law and TRIPS Agreement [D]. China University of Political Science and Law, 2011.

[7] Han Jingfeng. Reflections on the Development and Reform of China's Trademark Law under Management Thinking[J]. Intellectual Property, 2011(10): 38-43.

[8] Kong Jia. Overview of the Madrid System of International Trademark Registration and Analysis of Legal Hot Issues (Part II) [J]. Chinese Lawyer, 2011(4):81-83.

[9] Feng Xiaoqing. Recent Progress in the Revision of China's Trademark Law and Its Perfection Research (Continued)[J]. Journal of Shaoyang University (Social Science Edition), 2014(2): 9-17.

[10] Ni Zhuliang. Systematic Research on Trademark Prior Use System—-Taking "Influence” as the Main Line of Logic[J]. Journal of Zhejiang Gongshang University, 2015(5): 74-83.

[11] Zhang Yumin, ZHANGYu-min. Maintaining Fair Competition is the Fundamental Purpose of Trademark Law__ From the Perspective of the Revision of the Trademark Law[J]. Law Forum, 2008, 23(2): 30-36. 